\title{
A single-nucleotide polymorphism rs708567 in the IL-17RC gene is associated with a susceptibility to and the curve severity of adolescent idiopathic scoliosis in a Chinese Han population: a case-control study
}

\author{
Song Zhou ${ }^{\dagger}$, Xu-sheng Qiu ${ }^{\dagger}$, Ze-zhang Zhu', Wei-fei Wu, Zhen Liu and Yong Qiu*
}

\begin{abstract}
Background: Although the pathogenesis of adolescent idiopathic scoliosis (AIS) remains controversial, genetic factors are thought to play key roles in the development of AIS. In a recent genome-wide association study, a polymorphism in the interleukin-17 receptor C (IL-17RC) gene was reported to be associated with the susceptibility to AIS, implicating IL-17RC as a novel predisposing gene for AIS. However, as this association has not been replicated in other populations, its global applicability remains unclear.

Methods: A total of 529 Chinese girls with AIS and 512 healthy age-matched controls were recruited in this case-control study from June 2007 to December 2009. Polymerase chain reaction restriction fragment length polymorphism (PCR-RFLP) analysis was performed to detect the genotype of the single-nucleotide polymorphism (SNP) rs708567 in the IL-17RC gene. Case-control and case-only studies were performed to determine the association between the IL-17RC gene polymorphism and the susceptibility to and curve severity of AIS.

Results: The GG genotype and G allele frequencies were significantly higher in the AIS patients than in the controls $\left(x^{2}\right.$ test: $P=0.023$ and 0.028 , respectively). The risk for the GG genotype is 1.550-fold (95\% Cl: $1.062-2.261$ ) higher than the AG genotype, and the risk for the $G$ allele is 1.507 -fold (95\% Cl: 1.046 - 2.172) higher than the $A$ allele. Additionally, a subgroup of skeletally mature AIS patients $(n=241)$ who carried the GG genotype showed a significantly higher mean maximum Cobb angle than those carrying the AG genotype (36.01 $\pm 13.12^{\circ} \mathrm{vs}$. $\left.28.92 \pm 7.43^{\circ}, P=0.007\right)$.

Conclusions: This study confirms the significant association between the IL-17RC gene polymorphism and the susceptibility to and curve severity of AIS in a Chinese Han population, suggesting that the IL-17RC gene is an AIS-predisposing gene in Chinese Han population.
\end{abstract}

Keywords: Adolescent idiopathic scoliosis, IL-17RC, Single-nucleotide polymorphism

\footnotetext{
* Correspondence: scoliosis2002@sina.com

${ }^{\dagger}$ Equal contributors

Spine Surgery Department, the Affiliated Drum Tower Hospital of Nanjing University Medical School, Nanjing, China
} 


\section{Background}

Adolescent idiopathic scoliosis (AIS) is one of the most common spinal deformities, with a world-wide pediatric prevalence of 2-3\% [1]. In recent decades, many etiological factors have been proposed for AIS, such as uncoupled growth of the spinal column [2], paraspinal muscle dysfunction[3,4], hormonal disturbances [5-7], and inflammation[8]. However, no single factor can explain all of the clinical characteristics of AIS. Therefore, AIS is generally regarded as a multi-factorial disorder for which hereditary or genetic factors likely play important roles.

The genetic factors contributing to AIS have been described in many studies. Genome-wide linkage analysis studies have identified several variations in chromosomal regions, including 9q31.2-q34.2, 12p, 17p11 and so on [9-14], as being associated with an increased susceptibility to AIS. Through genetic association studies, several genes, such as tryptophan hydroxylase 1 (TPH1) [15], estrogen receptor $\alpha$ (ESR1) [16], and the matrilin-1 gene (MATN1) [17], have been identified as genes that predispose an individual to AIS. Furthermore, a number of genes have also been found to be related to the curve severity of AIS[18,19].

In a recent genome-wide association study using data from 137 AIS patients of European ancestry, Dormans JP et al.[20] reported that SNP rs708567 (a common missense mutation) was associated with susceptibility to AIS. SNP rs708567 is located on chromosome 3p25.3 and occurs in an exon of the IL-17 receptor C (IL-17RC) gene, which codes for an integral member of the IL-17R complex [21]. As an essential part of the IL-17 cytokine/ IL-17R signaling axis, the IL-17R complex mediates the signal transduction of the IL-17 cytokine family, which promotes the production of pro-inflammatory cytokines, such as tumor necrosis factor $\alpha$ (TNF- $\alpha)$, interleukin-1 $\beta$ (IL-1 $\beta$ ), and interleukin-6 (IL-6) [21]. The findings of Dormans JP et al. [20] identified IL-17RC as a novel predisposing gene for AIS, thus providing significant information regarding the genetic etiology of AIS.

However, due to the small sample sizes, population stratification, variability in the control population, and racial and ethnic differences, genetic association studies may produce spurious associations [22]. Therefore, the purpose of this case-control study was to replicate the previously reported association between the IL-17RC gene polymorphism and the susceptibility to AIS and to further investigate the contribution of this polymorphism to the curve severity of AIS within a Chinese Han population. Our results suggest that the IL-17RC gene is an AIS-predisposing gene in Chinese Han population.

\section{Methods}

This study included two sections: a case-control study and a case-only study.
The case-control study evaluated the genetic association between the predisposition to AIS and the rs708567 SNP within the IL-17RC gene. The case-only study evaluated the genetic association between rs708567 and curve severity in a subgroup of AIS patients who had reached skeletal maturity. Skeletal maturity was defined as being at least 16 years old and having a Risser sign of 5 (the Risser sign is a grading system for the ossification of the iliac apophysis)[23]. As treatments may change the natural history of AIS, patients who had received any previous treatment were initially excluded from the case-only study.

\section{Subjects}

A total of 698 Chinese girls with AIS, aged 11 to 18 years, and 512 gender- and age-matched controls were consecutively recruited at our scoliosis clinic from June 2007 to December 2009. A diagnosis of AIS was made according to a clinical examination and standard standing posteroanterior whole-spine radiography. The scoliosis curve severity was measured according to the Cobb method, and patients (529 cases) with a major Cobb angle ranging from $20^{\circ}$ to $100^{\circ}$ were included in the study. Patients (104 cases) with a curve less than $20^{\circ}$ were excluded because of a possible "false-positive" diagnosis of AIS, and patients (65 cases) with a curve greater than $100^{\circ}$ were also excluded because of a possible association with intraspinal and brain stem abnormalities. In addition, patients who were diagnosed with congenital scoliosis, neuromuscular diseases, endocrine diseases, skeletal dysplasia, connective tissue abnormalities or scoliosis secondary to some other disorder were excluded from the subset. The healthy controls were recruited during a regular school health-screening program. To rule out any spinal deformity, the Adam forward-bending test [24] was performed by an experienced orthopedic surgeon for all of the controls. In addition, no subjects showed evidence of bone disease or growth disturbances, systemic illness or other conditions known to affect bone metabolism or had a history of recent steroid intake.

The study protocols were approved by the University and Hospital Ethics Committee. Informed consent was obtained from all of the subjects and their parents prior to the DNA analysis.

\section{Blood sampling and genotyping}

As described by Dormans JP et al. [20], SNP rs708567 in the IL-17RC gene is associated with a susceptibility to AIS. The present study focused only on this SNP, and rs708567 genotyping was performed using PCR-RFLP (polymerase chain reaction restriction fragment length polymorphism) in the Chinese Han population described above. 
The total genomic DNA was extracted from 5 to $7 \mathrm{~mL}$ of ethylenediaminetetraacetic acid anti-coagulated whole blood from each patient using genomic DNA isolation kits (Amersham, Buckinghamshire, UK) according to the manufacturer's instructions. The DNA samples were frozen and stored until needed. Genotyping was performed using PCR-RFLP. The primers are listed in Table 1. The genomic DNA was amplified in a PCR volume of $10 \mu \mathrm{L}$ that contained $5 \mu \mathrm{L} 2 \times$ BenchTopTM Taq Master Mix, $0.2 \mu \mathrm{L}$ each primer $(1.0 \mu \mathrm{mol} / \mathrm{L}), 3.6 \mu \mathrm{L} \mathrm{ddH}_{2} \mathrm{O}$ and 1.0 $\mu \mathrm{L}$ genomic DNA $(1 \mu \mathrm{g})$. A typical PCR amplification program consisted of 40 amplification cycles of $30 \mathrm{~s}$ at $96^{\circ} \mathrm{C}, \quad 45 \mathrm{~s}$ at the primer-appropriate annealing temperature, and $30 \mathrm{~s}$ at $72^{\circ} \mathrm{C}$. A final elongation step was performed for $7 \mathrm{~min}$ at $72^{\circ} \mathrm{C}$. For restriction enzyme digestion, the PCR product was incubated with $4 \mathrm{U}$ of Hinfl for $4 \mathrm{~h}$ in the presence of the accompanying buffer. The digested PCR products were visualized by electrophoresis using a 3.5\% agarose gel. The genotyping results were validated by duplicate genotyping with $10 \%$ of the samples (Table 1).

\section{Statistical analyses}

A power analysis was performed using PASS (version 11; NCSS, Kaysville, UT; http://www.ncss.com/pass.html). The other statistical analyses were performed using SPSS 13.0 for Windows (SPSS Inc., Chicago, IL). HardyWeinberg equilibrium (HWE) was tested by a goodnessof-fit $\chi^{2}$ test. The case-control difference for the allele and genotype frequencies was analyzed using the $\chi^{2}$ test. The odds ratios (ORs) and 95\% confidence interval (95\% $\mathrm{CI}$ ) ranges were calculated. A one-way analysis of variance was used to compare the mean maximum Cobb angle of the different genotypes in the AIS patients. A Pvalue lower than 0.05 was considered to be statistically significant.

\section{Results}

A total of 529 Chinese AIS girls with a mean age of $14.54 \pm 1.62$ years and 512 gender- and age-matched controls with a mean age of $14.36 \pm 1.93$ years were recruited for this study. The mean Risser sign of the AIS patients and the mean maximum Cobb angle were $3.17 \pm 1.89$ (range $0-5$ ) and $38.30 \pm 16.71^{\circ}$ (range $20^{\circ}$ $100^{\circ}$ ), respectively. Our sample size had an $81 \%$ power to detect the AIS-relevant SNP within the IL-17RC gene. The genotype frequencies showed no significant deviation from Hardy-Weinberg equilibrium (HWE) in either the AIS group or control group. Of these 529 AIS patients, 241 patients (mean maximum Cobb angle of $35.24 \pm 12.81^{\circ}$ ) who had reached skeletal maturity were included in the case-only study.

\section{Association of SNP rs708567 with the susceptibility to AIS} The genotype and allele frequencies of SNP rs708567 in the AIS patients and controls are shown in Table 2. Overall, the frequencies of the GG genotype and the G allele in the AIS patients were significantly higher than in the controls (GG genotype, $90.17 \%$ vs. $85.55 \%$, respectively, $\mathrm{P}=0.023$; $\mathrm{G}$ allele, $95.1 \%$ vs. $92.8 \%$, respectively, $\mathrm{P}=0.028)$. The risk for the GG genotype is 1.550 -fold higher (95\% CI: 1.062 - 2.261) than the AG genotype, and the risk for the $\mathrm{G}$ allele is 1.507-fold higher (95\% CI: 1.046 - 2.172) than the A allele.

\section{Association of SNP rs708567 with curve severity in AIS}

We evaluated the association of SNP rs708567 with curve severity in a subset of AIS patients who had reached skeletal maturity $(n=241)$ in a case-only study. Overall, AIS patients with the GG genotype showed a significantly higher mean maximum Cobb angle $\left(36.01 \pm 13.12^{\circ}\right.$, range $\left.20-58^{\circ}\right)$ than those with the AG genotype $\left(28.92 \pm 7.43^{\circ}\right.$, range $\left.20-51^{\circ}, \mathrm{P}=0.007\right)$, indicating that SNP rs708567 is significantly associated with the curve severity of scoliosis (Table 3 ).

\section{Discussion}

Previous population studies have reported a significantly higher AIS incidence of $15.8 \%$ in first-degree relatives of AIS patients, $36 \%$ in dizygotic twins, and $73 \%$ in monozygotic twins $[25,26]$. In addition, a significantly higher incidence of AIS was found in females than males, with a female-to-male ratio of approximately 10:1[27]. Given the documented higher incidence of AIS within families and the sexual dimorphism of AIS occurrence, genetics may offer the best possibility to unravel the etiology of AIS.

A genetic association study is one of the most effective methods for identifying and characterizing the genomic variants that underlie the susceptibility to a

Table 1 Primers and restriction enzymes for PCR-RFLP analysis

\begin{tabular}{cccccc}
\hline SNP & Primers & $\begin{array}{c}\text { Annealing } \\
\text { Temperature }\left({ }^{\circ} \mathbf{C}\right)\end{array}$ & $\begin{array}{c}\text { PCR Product } \\
\text { Size (bp) }\end{array}$ & $\begin{array}{c}\text { Restriction } \\
\text { Enzyme }\end{array}$ & $\begin{array}{c}\text { Fragment Size After Enzymatic } \\
\text { Cleavage (bp) }\end{array}$ \\
\hline rs708567 & $\begin{array}{c}\text { Forward Primer: 5'- } \\
\text { AGTAGGGTAGGCCTGGAAGG-3' }\end{array}$ & 57 & 210 & Hinfl & GG: 210 \\
\cline { 2 - 6 } & $\begin{array}{c}\text { Reverse Primer: 5'- } \\
\text { CACTGGGAGAGCCTGAAGA-3' }\end{array}$ & & & & AG: $161+49$ \\
\hline
\end{tabular}

*PCR-RFLP, polymerase chain reaction restriction fragment length polymorphism; SNP, single-nucleotide polymorphism. 
Table 2 Distribution of the genotype and allele frequencies of SNP rs708567 in the IL-17RC gene in AIS patients ( $n=529)$ and controls $(n=512)$

\begin{tabular}{|c|c|c|c|c|c|}
\hline \multirow[t]{2}{*}{ SNP } & \multirow{2}{*}{$\begin{array}{c}\text { Genotype/ } \\
\text { Allele }\end{array}$} & \multicolumn{2}{|c|}{ Group, n (\%) } & \multirow{2}{*}{$\begin{array}{c}\text { P- } \\
\text { value }\end{array}$} & \multirow{2}{*}{$\begin{array}{c}\text { OR }(95 \% \\
\text { Confidence } \\
\text { Interval) }\end{array}$} \\
\hline & & AIS & Controls & & \\
\hline \multirow[t]{5}{*}{ rs708567 } & GG & 477 (90.17\%) & 438 (85.55\%) & 0.023 & $1.550(1.062-2.261)$ \\
\hline & $A G$ & $52(9.83 \%)$ & $74(14.45 \%)$ & & $0.645(0.442-0.941)$ \\
\hline & $\mathrm{AA}$ & - & - & & - \\
\hline & $G$ & $1006(95.1 \%)$ & $950(92.8 \%)$ & 0.028 & $1.507(1.046-2.172)$ \\
\hline & $A$ & $52(4.9 \%)$ & $74(7.2 \%)$ & & $0.664(0.460-0.956)$ \\
\hline
\end{tabular}

$\mathrm{OR}$, odds ratio. The data are presented as the no. of individuals and their percentage of the population tested. $\mathrm{A}$ value of $\mathrm{P}<0.05$ ( $x^{2}$ test) was considered to be statistically significant.

multifactorial disease [28]. However, the quality of genetic association may be affected by many factors, such as a small sample size, population stratification, and racial and ethnic differences, and false-positive associations may be produced. For example, Zhang et al. [29] initially reported that SNP rs1256120 in the estrogen receptor $\beta$ gene (ESR2) was associated with a higher susceptibility to and the curve severity of AIS in Chinese females using data from 176 AIS patients and 80 controls. However, Takahashi et al. [30] could not replicate this association in a Japanese population using data from 798 AIS patients and 637 controls. Therefore, Neale et al. [31] advocated that any positive association findings in genebased studies should be confirmed in a different population using a larger sample size.

In a recent genetic association study, Dormans JP et al. [20] reported that SNP rs708567 (a common missense mutation) in the IL-17RC gene is associated with a higher susceptibility to AIS in a population of European ancestry, suggesting that IL-17RC may be an AIS susceptibility gene. However, in a subsequently published association study using data from 419 American AIS patients and their families, Sharma $S$ et al. [1] did not find the association between the IL-17RC gene polymorphism and the susceptibility to AIS. Furthermore, Takahashi Y et al. [32] also did not report the association between this SNP and an AIS predisposition in Japanese female adolescents in another genome-wide association study. Therefore, it is necessary to perform an additional study to confirm the results for SNP rs708567.

In the present study, we re-evaluated the association between SNP rs705867 and the predisposition to AIS using data from a Chinese Han population. Our results show that both the GG genotype and $G$ allele have a significantly higher frequency in AIS patients than the controls $(\mathrm{P}=0.023$ and $\mathrm{P}=0.028$, respectively). Our results are consistent with the finding of Dormans JP et al. [20], confirming that IL-17RC is a novel predisposition gene for AIS. The discrepancy between these results may reflect the issue of heterogeneity to detect modest effect sizes. In addition, our results further revealed that AIS patients with the GG genotype have a higher mean maximum Cobb angle than those with the AG genotype, indicating that the IL-17RC gene polymorphism is also associated with the curve severity in AIS patients.

The human IL-17RC gene on chromosome 3 contains 19 exons and spans 16,550 bp within the chromosomal region $3 p 25.3$ to $3 p 24.1$. The $\mathrm{IL}-17 \mathrm{RC}$ gene encodes a single-pass type I transmembrane protein (IL-17 receptor C, IL-17RC), which was characterized as an integral part of the IL-17 receptor (IL-17R) complex [21]. The IL-17R complex mediates IL-17 effector function through the IL-17 cytokine/IL-17R complex signaling axis, and current evidence indicates that both the dysfunction of IL-17RC and the IL-17 cytokine/IL-17R signaling axis are implicated in a number of human diseases. As expected, given its central role in regulating inflammation, dysfunctions in the IL-17 cytokine/IL-17R signaling axis can promote the production of several pro-inflammatory cytokines, such as tumor necrosis factor $\alpha$ (TNF- $\alpha)$, interleukin-1 $\beta$ (IL-1 $\beta)$ and interleukin- 6 (IL-6), and increase the activity of metalloproteinases (MMPs), which play important roles in disc degeneration [33]. Furthermore, recent studies have also shown that an impaired IL-17 cytokine/IL-17R signaling axis drives the pathogenesis of bone destruction, in part by inducing the expression of RANKL in osteoblasts [34-36].

Table 3 Association of the IL-17RC gene polymorphism with curve severity in AIS patients who had reached skeletal maturity

\begin{tabular}{cccc}
\hline SNP & Genotype & Number of Subjects & Mean Maximum Cobb Angle (Mean \pm SD) \\
\hline rs708567 & GG & 215 & $36.01 \pm 13.12$ \\
\cline { 2 - 3 } & AG & 26 & $28.92 \pm 7.43$ \\
\hline
\end{tabular}

A value of $P<0.05$ (one-way analysis of variance) was considered to be statistically significant. 
Thus, regarding the role of IL-17RC and/or the IL-17 cytokine/IL-17R signaling axis in disc and bone destruction, the rs708567 polymorphism may impair the function of the IL-17RC gene and accelerate disc degeneration and bone destruction, which may lead to the occurrence and progression of scoliosis. Indeed, defects within the discs and bones of AIS patients have been widely described in previous studies $[37,38]$.

Overall, we found a positive association between SNP rs708567 and the susceptibility to and curve severity of AIS in a Chinese Han population. Unfortunately, the specific influence of SNP rs708567 on IL-17RC gene function remains unknown. As described by Dormans JP et al., SNP rs708567 is a common missense mutation (S111 L) within the IL-17RC gene, suggesting that synergistic interactions between SNP rs708567 and other polymorphisms may play an important role in impairing IL-17RC gene function. Therefore, further investigations will be performed using the method of pair-wise linkage disequilibrium (LD) analysis in our next study to clarify the possible synergistic interactions between SNP rs708567 and other polymorphisms and their effect on the susceptibility to AIS. In addition, a potential limitation that should not be ignored is the false-negative result of the Adam forward-bending test, which may lead to an ascertainment bias with regard to the controls. Therefore, further investigations using other samples are necessary to confirm this positive association.

\section{Conclusions}

This study identified a significant association between an IL-17RC gene polymorphism and the susceptibility to and curve severity of AIS in a Chinese Han population, indicating that IL-17RC is a predisposing gene for AIS with a single thoracic curve. However, further studies are necessary to confirm these positive findings in other ethnicities.

\section{Competing interests}

The authors declare that they have no competing interests.

\section{Authors' contributions}

SZ, XSQ and ZZZ performed the genetic studies. WFW recruited patients and was involved in the clinical part of the investigation. ZL performed the statistical analysis. YQ conceived the study, participated in its design and coordination and helped to draft the manuscript. All of the authors read and approved the final manuscript.

\section{Acknowledgements}

We gratefully recognize the financial support of the Nanjing Medical Science and technique Development Foundation and the National Natural Science Foundation of China (NO. 81171767 and NO. 30901570).

Received: 10 March 2012 Accepted: 14 September 2012 Published: 21 September 2012

\section{References}

1. Sharma S, Gao X, Londono D, Devroy SE, Mauldin KN, Frankel JT, Brandon JM, Zhang D, Li QZ, Dobbs MB, Gurnett CA, Grant SF, Hakonarson H, Dormans JP, Herring JA, Gordon D, Wise CA: Genome-wide association studies of adolescent idiopathic scoliosis suggest candidate susceptibility genes. Hum Mol Genet 2011, 20:1456-1466.

2. Guo X, Chau WW, Chan YL, Cheng JC: Relative anterior spinal overgrowth in adolescent idiopathic scoliosis Results of disproportionate endochondral membranous bone growth. J Bone Joint Surg Br 2003, 85:1026-1031.

3. Spencer GS, Eccles MJ: The proportion and size of type 1 and type 2 skeletal muscle fibres measured using a computer-controlled microscope. J Neurol Sci 1976, 30:143-154.

4. Dastych $M$, Vlach O: Zinc status in patients with idiopathic scoliosis. Spine (Phila Pa 1976) 1990, 15:65-66.

5. Machida M, Saito M, Dubousset J, Yamada T, Kimura J, Shibasaki K: Pathological mechanism of idiopathic scoliosis: experimental scoliosis in pinealectomized rats. Eur Spine J 2005, 14:843-848.

6. Machida M, Dubousset J, Yamada T, Kimura J, Saito M, Shiraishi T, Yamagishi M: Experimental scoliosis in melatonin-deficient C57BL/6J mice without pinealectomy. J Pineal Res 2006, 41:1-7.

7. Moreau A, Wang DS, Forget S, Azeddine B, Angeloni D, Fraschini F, Labelle H, Poitras B, Rivard CH, Grimard G: Melatonin signaling dysfunction in adolescent idiopathic scoliosis. Spine (Phila Pa 1976) 2004, 29:1772-1781.

8. Aulisa L, Papaleo P, Pola E, Angelini F, Aulisa AG, Tamburrelli FC, Pola P, Logroscino CA: Association between IL- 6 and MMP-3 gene polymorphisms and adolescent idiopathic scoliosis a case-control study. Spine (Phila Pa 1976) 2007, 32:2700-2702.

9. Ocaka L, Zhao C, Reed JA, Ebenezer ND, Brice G, Morley T, Mehta M, O'Dowd J, Weber JL, Hardcastle AJ, Child AH: Assignment of two loci for autosomal dominant adolescent idiopathic scoliosis (AIS) to chromosomes 9q31.2q34.2 and 17q25.3-qtel. J Med Genet 2008, 45:87-92.

10. Alden KJ, Marosy B, Nzegwu N, Justice CM, Wilson AF, Miller NH: Idiopathic scoliosis: identification of candidate regions on chromosome 19p13. Spine (Phila Pa 1976) 2006, 31:1815-1819.

11. Raggio CL, Giampietro PF, Dobrin S, Zhao C, Dorshorst D, Ghebranious N, Weber JL, Blank RD: A novel locus for adolescent idiopathic scoliosis on chromosome12p. J Orthop Res 2009, 27:1366-1372.

12. Gurnett CA, Alaee F, Bowcock A, Kruse L, Lenke LG, Bridwell KH, Kuklo T, Luhmann SJ, Dobbs MB: Genetic linkage localizes an adolescent idiopathic scoliosis and pectus excavatum gene to chromosome 18q. Spine (Phila Pa 1976) 2009, 34:E94-E100.

13. Salehi LB, Mangino M, De Serio S, De Cicco D, Capon F, Semprini S, Pizzuti A, Novelli G, Dallapiccola B: Assignment of a locus for autosomal dominant idiopathic scoliosis (IS) to human chromosome 17p11. Hum Genet 2002, 111(4-5):401-404.

14. Edery P, Margaritte-Jeannin P, Biot B, Labalme A, Bernard JC, Chastang J, Kassai B, Plais MH, Moldovan F, Clerget-Darpoux F: New disease gene location and high genetic heterogeneity in idiopathic scoliosis. Eur J Hum Genet 2011, 19:865-869.

15. Wang H, Wu Z, Zhuang Q, Fei Q, Zhang J, Liu Y, Wang Y, Ding Y, Qiu G: Association study of tryptophan hydroxylase 1 and arylalkylamine $\mathrm{N}$ acetyltrans-ferase polymorphisms with adolescent idiopathic scoliosis in Han Chinese. Spine (Phila Pa 1976) 2008, 33:2199-2203.

16. Wu J, Qiu Y, Zhang L, Sun Q, Qiu X, He Y: Association of estrogen receptor gene polymorphisms with susceptibility to adolescent idiopathic scoliosis. Spine (Phila Pa 1976) 2006, 31:1131-1136.

17. Qiu XS, Tang NL, Yeung HY, Lee KM, Hung WW, Ng BK, Ma SL, Kwok RH, Qin L, Qiu Y, Cheng JC: Melatonin receptor 1B (MTNR1B) gene polymorphism is associated with the occurrence of adolescent idiopathic scoliosis. Spine (Phila Pa 1976) 2007, 32:1748-1753.

18. Inoue M, Minami S, Nakata Y, Kitahara H, Otsuka Y, Isobe K, Takaso M, Tokunaga M, Nishikawa S, Maruta T, Moriya H: Association between estrogen receptor gene polymorphisms and curve severity of idiopathic scoliosis. Spine (Phila Pa 1976) 2002, 27:2357-2362.

19. Yeung HY, Tang NL, Lee KM, Ng BK, Hung WW, Kwok R, Guo X, Qin L, Cheng JC: Genetic association study of insulin-like growth factor-I (IGF-I) gene with curve severity and osteopenia in adolescent idiopathic scoliosis. Stud Health Technol Inform 2006, 123:18-24.

20. Dormans JP, Grant SFA, Rendon N, Mentch FD, Kim CE, Frackelton EC, Bradfield JP, Zhang H, Chiavacci RM, Hakonarson $\mathrm{H}$ : A genome wide association study identifies an ILI7RC missense mutation (S111 L) as an adolescent idiopathic scoliosis locus. 60th Am Soc Hum Genet Meet. Washington DC: Platform Session 51: Polygenic Traits: GWAS Methods and Results; 2010:99. November 2. 
21. Allen WH, Gaffen SL: IL-17RC: a partner in IL-17 signaling and beyond. Semin Immunopathol 2010, 32:33-42.

22. Ioannidis JP, Ntzani EE, Trikalinos TA, Contopoulos-loannidis DG: Replication validity of genetic association studies. Nat Genet 2001, 29:306-309.

23. Risser JC: The iliac apophysis: an invaluable sign in the management of scoliosis. Clin Orthop Relat Res 1958, 11:111-119.

24. Adams W: Lectures on the Pathology and Treatment of Lateral and Other Forms of Curvature of the Spine. London: Churchill; 1865.

25. Riseborough EJ, Wynne-Davies RA: A genetic survey of idiopathic scoliosis in Boston, Massachusetts. J Bone Joint Surg Am 1973, 55:974-982.

26. Kesling KL, Reinker KA: Scoliosis in twins. a meta-analysis of the literature and report of six cases. Spine (Phila Pa 1976) 1997, 22:2009-2014.

27. Ohtsuka Y, Yamagata M, Arai S, Kitahara H, Minami S: School screening for scoliosis by the Chiba University Medical School screening program: results of 1.24 million students over an 8-year period. Spine (Phila Pa 1976) $1988,13: 1251-1257$.

28. Andrew TH, Mark IMC: What makes a good genetic association study? Lancet 2005, 366:1315-1323.

29. Zhang HQ, Lu SJ, Tang MX, Chen LQ, Liu SH, Guo CF, Wang XY, Chen J, Xie $L$ : Association of estrogen receptor beta gene polymorphisms with susceptibility to adolescent idiopathic scoliosis. Spine (Phila Pa 1976) 2009, 34:760-764.

30. Takahashi Y, Matsumoto M, Karasugi T, Watanabe K, Chiba K, Kawakami N, Tsuji T, Uno K, Suzuki T, Ito M, Sudo H, Minami S, Kotani T, Kono K, Yanagida H, Taneichi H, Takahashi A, Toyama Y, Ikegawa S: Replication study of the association between adolescent idiopathic scoliosis and two estrogen receptor genes. J Orthop Res 2011, 29:834-837.

31. Neale BM, Sham PC: The future of association studies: gene-based analysis and replication. Am J Hum Genet 2004, 75:353-362.

32. Takahashi Y, Kou I, Takahashi A, Johnson TA, Kono K, Kawakami N, Uno K, Ito M, Minami S, Yanagida H, Taneichi H, Tsuji T, Suzuki T, Sudo H, Kotani T, Watanabe K, Chiba K, Hosono N, Kamatani N, Tsunoda T, Toyama Y, Kubo M, Matsumoto M, Ikegawa S: A genome-wide association study identifies common variants near LBX1 associated with adolescent idiopathic scoliosis. Nat Genet 2011, 43:1237-1240.

33. Deborah AS, Donny LFC, Wilson SC: Interleukin-1 $\beta$ and tumor necrosis factor-a decrease collagen synthesis and increase matrix metalloproteinase activity in cardiac fibroblasts in vitro. Circ Res 2000, 86:1259-1265

34. Sato K, Suematsu A, Okamoto K, Yamaguchi A, Morishita Y, Kadono Y, Tanaka S, Kodama T, Akira S, Iwakura Y, Cua DJ, Takayanagi H: Th17 functions as an osteoclastogenic helper T cell subset that links $\mathrm{T}$ cell activation and bone destruction. J Exp Med 2006, 203:2673-2682.

35. Kotake S, Udagawa N, Takahashi N, Matsuzaki K, Itoh K, Ishiyama S, Saito S, Inoue K, Kamatani N, Gillespie MT, Martin TJ, Suda: TIL-17 in synovial fluids from patients with rheumatoid arthritis is a potent stimulator of osteoclastogenesis. J Clin Invest 1999, 103:1345-1352.

36. Huang H, Kim HJ, Chang EJ, Lee ZH, Hwang SJ, Kim HM, Lee Y, Kim HH: IL17 stimulates the proliferation and differentiation of human mesenchymal stem cells: implications for bone remodeling. Cell Death Differ 2009, 16:1332-1343.

37. Périé $D$, Curnier D: Effect of pathology type and severity on the distribution of MRI signal intensities within the degenerated nucleus pulposus: application to idiopathic scoliosis and spondylolisthesis. BMC Musculoskelet Disord 2010, 26(11):189.

38. Qiu Y, Sun X, Qiu X, Li W, Zhu Z, Zhu F, Wang B, Yu Y, Qian B: Decreased circulating leptin level and its association with body and bone mass in girls with adolescent idiopathic scoliosis. Spine (Phila Pa 1976) 2007, 32:2703-2710

doi:10.1186/1471-2474-13-181

Cite this article as: Zhou et al: A single-nucleotide polymorphism rs708567 in the IL-17RC gene is associated with a susceptibility to and the curve severity of adolescent idiopathic scoliosis in a Chinese Han population: a case-control study. BMC Musculoskeletal Disorders 2012 13:181.

\section{Submit your next manuscript to BioMed Central and take full advantage of:}

- Convenient online submission

- Thorough peer review

- No space constraints or color figure charges

- Immediate publication on acceptance

- Inclusion in PubMed, CAS, Scopus and Google Scholar

- Research which is freely available for redistribution 